\title{
CALCIUM CONTENT IN MILK BRANDS AVAILABLE IN NAGPUR MARKET, MAHARSHTRA, INDIA.
}

\author{
Rashmi R. Gupta*, Anjali S. Mahakalakar** \\ *Shri Mathuradas Mohota Science college, Nagpur \\ **Sevadal Mahila Mahavidyalaya, Nagpur \\ Corresponding author : anjalim1@rediffmail.com
}

\begin{abstract}
:
The present study was carried out to determine the amount of calcium in milk samples from different sources. Milk samples were collected from desi cow, buffalo, goat and commercially available packaged milk available in Nagpur market. In all 33 samples were collected and calcium content was determined by EDTA titration method. The amount of Calcium was highest in goat milk and lowest in milk powders.
\end{abstract}

Keywords:- Calcium content, Milk samples.

\section{INTRODUCTION:}

Milk is a nutrient rich, white liquid food produced by the mammary glands of mammals. It is the primary source of nutrition for infant mammals before they are able to digest other types of food. The role of milk in nature is to nourish and provide immunological protection for the mammalian young .Milk can be described as an oil-inwater emulsion with the fat globules dispersed in the continuous phase, a colloid suspension of casein micelles, globular proteins and lipoprotein particles and a solution of lactose, soluble proteins, minerals, vitamins and other components [1].

India is the world's largest producer of milk and is the leading exporter of skimmed milk powder [2][3]. The ever-increasing rise in domestic demand for dairy products and a large demand supply gap could lead to India being a net importer of dairy products in the future [4]. Milk is processed into variety of products such as cream, butter, cheese, yoghurt, ghee, curd, khoa, butter milk, paneer, ice cream etc. Modern industrial processes use milk to produce casein, whey protein, lactose, condensed milk, powdered milk and many other food additives and industrial product [5]. Milk has energy required for human activities and nutrients needed for building up the human body [6]. Calcium is one important component contributed by milk to human body. Various available Milks can differ in their Calcium content. Hence, this work was planned to assess and estimate the calcium content in the milks from markets and some animals whose Milk is used by humans. This estimation may be useful to decide about selection of milk for human consumption in case of calcium deficiency or its prevention.

\section{Source}

Sources of milk from domesticated animal include milk, not only of cattle but also of sheep, goat and buffalo [7]. Other cows include Ayrshire, Brown Swiss, Guernsey and Jersey. In Egypt buffaloes are used mainly for milk production. In India most of the people consume milk of cattle like Jersey and Buffalo. In developed countries, dairy cattle such as Holstein have bred selectively for increased milk production. Buffalo milk is pure white because it does not have carotene which is processed into vitamin A. The main components of goat milk are similar to those of cow milk but differ as to particular physical and chemical properties. Goat milk proteins and fats have differences in their composition from the milk of other species. Goat milk was found to contain more of calcium and phosphorus than cow and human milk [8]. 


\section{Composition}

Milk is a complex biological fluid consisting of fats, proteins, minerals, vitamins, enzymes, and sugar. Milk of all mammals contains proteins, fats, carbohydrates, vitamins, minerals and water., but their content varies widely between ruminants and non-ruminant milk. The milk composition differs considerably due to genetic factors, physiological factors, nutritional factors, frequency of milking, and environmental conditions. The greatest changes in composition occur during lactation. Colostrum, the first milk after calving has a high concentration of fat and protein, especially immunoglobulin, and a low concentration of lactose. The volume of milk produced increases during the early stages, which after peaking slowly declines towards the latter stages of lactation. The mastitis results in changed composition of milk with decreased levels of lactose and potassium and increased levels of sodium, chloride, and serum proteins. In addition, a large number of somatic cells and bacteria are present. Generally, the animals on nutritionally superior feed produce more milk with a higher level of fat and protein than animals on feed of lower nutritional quality. The fat content and protein content of milk are positively correlated within the population of dairy cattle; however, different breeds of cattle vary in average component levels. [9] Calcium and bioavailability: While it is possible to achieve adequate calcium intake and meet calcium requirements with a Western plant-based diet, it is easier and more practical to meet these requirements when milk and milk products are present in the diet. Furthermore, the contribution of milk and milk products to calcium intake is important and advantageous nutritionally. The replacement of milk and milk products with calciumequivalent foods has been shown to be detrimental to the overall nutritional profile, including the intake of other essential nutrients such as protein, magnesium, phosphorus, and vitamins A, D, $\mathrm{B}_{2}$ (riboflavin) and $\mathrm{B}_{12 \cdot} \cdot[10,11]$
The calcium bioavailability of some fortified foods is comparable with that of milk, but these foods do not always provide the same total calcium content per serving. Studies on fortified beverages, including soy beverages and orange juice, have shown that the fortification tends to settle to the bottom of the carton and that even vigorous shaking may not be enough to re-suspend the calcium salts.[12]

\section{The ROLE of calcium in milk}

Calcium is an important nutrient involved in the health of bone. The calcium as a bioactive mineral is demonstrated widely in a range of calcium- fortified foods, including modified milk and beverages. In the diets of developed countries, milk and dairy products provide approximately $70 \%$ of the recommended daily intake of $\mathrm{Ca}$. Its role as a protective factor in the etiology of colon cancer has been well documented. It is also believed to be associated with binding and removal of carcinogenic agents along the gastrointestinal tract. The calcium is important for the development of and maintenance of skeletal integrity and prevention of osteoporosis. Hypertension is another disease that is related to a low Calcium in-take. It is also showed that the people who ingest diets low in sodium and high in potassium, magnesium, and calcium do not have hypertension and cardiovascular disease.

\section{The normal calcium level in blood is 8.6- $10.3 \mathrm{mg} / \mathrm{dl}$. Hypocalcaemia}

Hypocalcaemia, commonly known as calcium deficiency disease, occur when calcium levels in the blood are low, along term deficiency can lead to dental changes, cataracts, alterations in the brain and osteoporosis which cause the bones to become brittle. Complication hypocalcaemia can be like threatening, and if the condition these untreated, it could eventually lead to death. 


\section{Hypercalcemia}

Excess intake of calcium may cause hypercalcemia. However, because calcium is absorbed rather inefficiently by the intestines, high serum calcium is more likely caused by excessive secretion of parathyroid hormone (PTH) or possibly by excessive intake of vitamin $\mathrm{D}$, both which facilitate calcium absorption. All these conditions result in excess calcium salts being deposited in the heart, blood vessels, or kidneys. Symptoms include anorexia, nausea, vomiting, memory loss, confusion, muscle weakness, increased urination, dehydration, and metabolic bone diseases.

Hypercalcemia is a condition in which the calcium level in yours blood is above normal. Too much calcium in your blood can weaken your bones, create kidney stones, and interfere with how your heart and brain work.

\section{What are the symptoms?}

The symptom described below may become worse as the disease progresses.

Muscles aches, cramps and spasms are earliest signs of a calcium deficiency. People tend to feel pain in the thighs and arms, particularly the underarms, when walking and otherwise moving.

A calcium deficiency can also cause numbness and tingling in the hand's arms feet, legs, around mouth.

Neuromuscular excitability, which potentially cause tetany and disruption of conductivity in cardiac tissue.

Bone disease

As calcium is heavily involved in bone manufacture, many Bone disease can be traced to problems with the organic matrix or the hydroxyapatite in molecular structure or organization. For example, osteoporosis is a reduction in mineral content of bone per unit volume, and can be treated by supplementation of calcium, vitamin $\mathrm{D}$, and bisphosphates. Calcium supplements may benefit the serum lipid in women who have passed menopause as well as older men; in post-menopausal women calcium supplementation as also appears to be inversely correlated with cardiovascular disease. Inadequate amounts of calcium, vitamin $\mathrm{D}$, or phosphates can lead to the softening of bones, known as osteocalcin.

\section{MATERIALS AND METHODS:}

\section{Collection of milk samples}

Milk samples of cow, goat and buffalo were procured from village of Khapa and commercially available packaged milk samples of AMUL, HALDIRAM, PRABHAT, DINSHAW, GOWARDHAN, MOTHER DAIRY, NESTLE MILK POWDER and BRITANNIA MILK POWDER were purchased from Nagpur Market. The fresh milk samples were collected in properly cleaned and washed bottles. All milk samples were brought to laboratory for estimating amount of Calcium. Estimation of Calcium of various milk samples was carried out by EDTA titration method[14].

\section{Preparation of solutions}

0.01 M EDTA solution: $3.7224 \mathrm{gm}$ of disodium salt of EDTA was weighed, dissolved in distilled water and then volume was raised to $1 \mathrm{~L}$.

\section{$0.01 \mathrm{M} \mathrm{ZnSO}_{4}$ solution as primary} standard: $0.1614 \mathrm{~g}$ of zinc sulphate heptahydrate was weighed, dissolved in distilled water. Two drops of dilute sulphuric acid were added to this before raising the volume to $100 \mathrm{ml}$.

\section{Ammonia-Ammonium Chloride ( $\left.\mathbf{N H}_{4} \mathrm{Cl}\right)$} solution as buffer (pH= 10): $17.5 \mathrm{gm}$ of Ammonium chloride was mixed with $142 \mathrm{ml}$ of concentrated Ammonia (Sp. Gravity0.880.90) and made up to $250 \mathrm{ml}$ with distilled water. $\mathrm{pH}$ was adjusted by $\mathrm{pH}$ meter (EQUIPTRONICS, MUMBAI, India) up to 10.

Eriochrome black-T: 0.2 gm of Eriochrome Black $\mathrm{T}$ was dissolved in $20 \mathrm{ml}$ of absolute alcohol.

Amount of calcium was determined as follows:

Molarity of Calcium $=\frac{\text { Molarity of EDTA X MBR }}{\text { Volume of milk }}$ 
Amount of Calcium

$=\frac{\text { Molecular weight of CalciumX Molarity of calcium }}{1}$

\section{RESULTS AND DISCUSSION}

Calcium content of various milk samples was determined without subjecting the milk samples to boiling. 33samples (11 brands in triplicate) were tested. The observations are summarised in Table 1 and Chart 1 . These values indicate that the highest Calcium content was found in Goat milk $(0.85 \mathrm{~g} / 1)$, followed by cow milk $(0.79 \mathrm{~g} / 1)$, Haldirams milk $(0.78 \mathrm{~g} / 1)$ and then buffalo milk (0.75gm/1 [13]. Amul, Dinshaw, Gowardhan, Mother's dairy, and milk powder recorded lower calcium content as compare to Goat, cow and buffalo milk respectively. Commercially available milk powders recorded lowest calcium content.

\section{CONCLUSION:}

Thus, our work showed that calcium content in the milk sample of Britannia milk powder is least $0.11(\mathrm{~g} / \mathrm{l})$ and that of Goat milk is maximum 0.85 (g/1). Cow's milk 0.79 $(0.79 \mathrm{~g} / 1)$ and Haldiram's milk 0.78 (g/l) showed comparatively good values of calcium content. Buffalo milk also showed 0.75 (g/l) value of calcium content, among the samples studied, available from Nagpur local market.

\section{REFERENCES}

Douglas Goff,PhD, professor of food science at the university of Guelph in Ontario, Canada, stated on his Dairy Chemistry and Physics (2007).

Anand kumar (2010-10-21). India, emerging as a leading milk product exports to check prices. timesofindiaeconomictimes.

Government scraps incentive on milk powder exports to check prices. timesofindia-economictimes.

Milk quality in India. milk production.com. November 6, 2016.

Milk. (2016, July 06). Retrived from https://en.wikipedia.org/wiki/Milk

Yoo S.H., Kang S. B., Park J.H., Lee K.S., Kim J.M. and Hoon S. S .(2013). Effect of heat-treat methods on the soluble calcium levels in the commercial milk products. Korean J. Food Sci.Animal Resources. 33(3):369376.

Imran M., Khan H.,bHassan, S.S. and Khan R.(2008). Physicochemical characteristics of various milk samples available in Pakistan. J. Zhejiang Univ. Sci. 9(7): 546-551.

Belewu M. A. and Aiyegbusi O.F. Comparison of the mineral content and apparent biological value of milk from human, crow and goat. (2002).J.Food Tech.Africa. 7(1):911.

Reference Encyclopedia of Food and Health, Vol 3, pp741-747, (2016)

(Ref: Fulgoni V 3rd et al. Nutrients from dairy foods are difficult to replace in diets of Americans: Food pattern modeling and an analyses of the National Health and Nutrition Examination Survey 20032006. Nutr Res 2011;31(10):75965.

Nicklas TA et al. The role of dairy in meeting the recommendations for shortfall nutrients in the American diet. $J A m$ Coll Nutr 2009;28(suppl 1):73S$81 \mathrm{~S}$.

Chalupa-Krebzdak $\mathrm{S}$ et al. Nutrient density and nutritional value of milk and plant-based milk alternatives. I Dairy J, 2018;87:84-92.

Pingle S A, Pawar V R, Bhagde R V. Titrimetric estimation of Calcium from different milk samples from Sangamner taluka, Maharashtra, Trends in Life Sciences Issue 3, Vol (5), 2016

Camp U.D.L. and Seely O. (06/082016) Complexometric Determination of calcium Retrieved from http://www.csudh.edu/oliver/che2 30/labmanual/calcium.html 
Table 1: Calcium content in milk samples

\begin{tabular}{|c|l|c|c|c|c|}
\hline \multirow{2}{*}{ Sr. No. } & \multicolumn{1}{|c|}{ Sample } & \multicolumn{2}{|c|}{ Amount of Calcium content gm/10 mL } & Amount of \\
\cline { 3 - 6 } & & I & II & III & $\begin{array}{c}\text { Calcium } \\
\text { (gm/mL) }\end{array}$ \\
\hline 1 & Amul Milk & 0.56 & 0.57 & 0.57 & 0.57 \\
\hline 2 & Dinshaw Milk & 0.61 & 0.63 & 0.63 & 0.63 \\
\hline 3 & Haldiram's Milk & 0.78 & 0.78 & 0.79 & 0.78 \\
\hline 4 & Prabhat Milk & 0.33 & 0.31 & 0.31 & 0.31 \\
\hline 5 & Cow Milk & 0.82 & 0.79 & 0.79 & 0.79 \\
\hline 6 & Buffalo Milk & 0.75 & 0.75 & 0.78 & 0.75 \\
\hline 7 & Goat Milk & 0.87 & 0.85 & 0.85 & 0.85 \\
\hline 8 & $\begin{array}{l}\text { Mother's Dairy } \\
\text { Milk }\end{array}$ & 0.66 & 0.64 & 0.64 & 0.64 \\
\hline 9 & Gowardhan Milk & 0.29 & 0.29 & 0.27 & 0.29 \\
\hline 10 & $\begin{array}{l}\text { Nestlé Milk } \\
\text { Powder }\end{array}$ & 0.17 & 0.14 & 0.14 & 0.14 \\
\hline 11 & $\begin{array}{l}\text { Britannia Milk } \\
\text { Powder }\end{array}$ & 0.11 & 0.11 & 0.11 & 0.11 \\
\hline
\end{tabular}

Table 2: Concentration of Calcium in respective milk brand

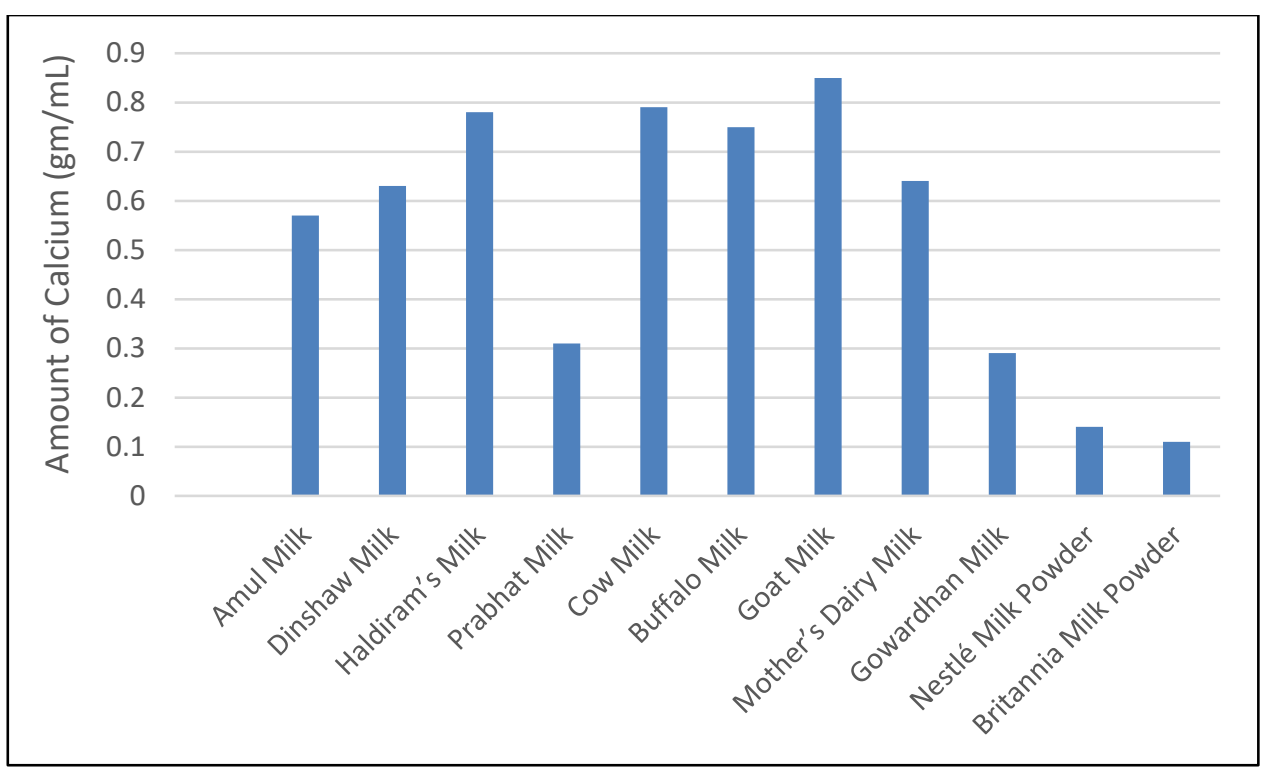

